\title{
ATRIAL NATRIURETIC PEPTIDE GENE AND PLASMA PRO-ANP CONCENTRATION IN PATIENTS WITH PRIMARY OPEN-ANGLE GLAUCOMA
}

\author{
Kristīne Baumane*, Liāna Pliss**, and Guna Laganovska* \\ * Rīga Stradiṇš University, Dzirciema ielā 16, Rīga, LV-1007, LATVIA \\ E-mail: baumanek@ml.Iv \\ ** Biomedical Research and Study Centre, Rātsupītes ielā 1, Rīgā, LV-1067, LATVIA
}

Communicated by Pauls Pumpēns

\begin{abstract}
Atrial natriuretic peptide (ANP) appears to have a physiological role in volume and pressure homeostasis. Increased cardiac expression and synthesis of ANP suggest a possible local paracrine function in a number of tissues including the eye. Therefore, the identification of genetic markers may prove to be an important advance in the diagnosis of patients with glaucoma and hypertension. Plasma pro-ANP concentration was measured in 30 clinical patients. A significant elevated level of prehormone was observed in glaucoma patients with blood hypertension. Also, the distribution of the genotypes and alleles of the Hpall, Smal and Scal polymorphisms of the ANP gene was examined in 20 hypertensive patients with glaucoma and normotensive controls. The frequencies of the ANP genotypes and alleles did not differ significantly between controls and hypertensive patients. PCR-RFLP (polymerase chain reaction-restriction fragment length polymorphism) analysis shows a T2238 $\rightarrow C$ transition in three hypertensive patients within the stop codon leading to the translation of ANP with an additional arginine. In the current study we also searched for any alterations in the 5' proximal promoter region of the ANP gene (-595 bp -384 bp) in 20 glaucoma patients with hypertension using PCR-based SSCP (single-strand conformation polymorphism) analysis. No significant alterations in the $5^{\prime}$ proximal promoter region of the ANP gene were observed among hypertensive patients. The structure of the ANP hormone encoded gene suggests potential importance in various diseases, but the regulatory function of ANP in the eye requires further investigations.
\end{abstract}

Key words: ANP gene, polymorphic restriction sites, pro-ANP level, primary open-angle glaucoma.

\section{INTRODUCTION}

Human body has two major groups of factors that regulate sodium and water balance: humoral and neurogene factors. One of the main factor groups is the natriuretic peptide family, which consists of four molecule groups that share significant amino acid sequence homological characteristics and a looped motif. In 1981, de Bold and colleagues made the seminal observation that infusion of extracts of atrial tissue into rats caused a copious natriuresis (de Bold et al., 1981). Natriuretic peptides (NP) are classified into three groups: A, B and C (Rosenzweig and Seidman, 1991). All of them contain a 17 -amino acid ring closed by a disulfide bond between two cysteine residues. Group A consists of an atrial natriuretic peptide (ANP) and urodilatine, secreted in waterworks. Group B contains brain natriuretic peptide (BNP), also known as ventricular natriuretic peptide (Fig. 1), which is a cardiac hormone secreted predominantly from the ventricle, and aldosterone-inhibiting factor (ASIF)
(Lang et al., 1990). Group C consists of a C natriuretic peptide (CNP) with 22-aminoacid rings. ANP appears to have a

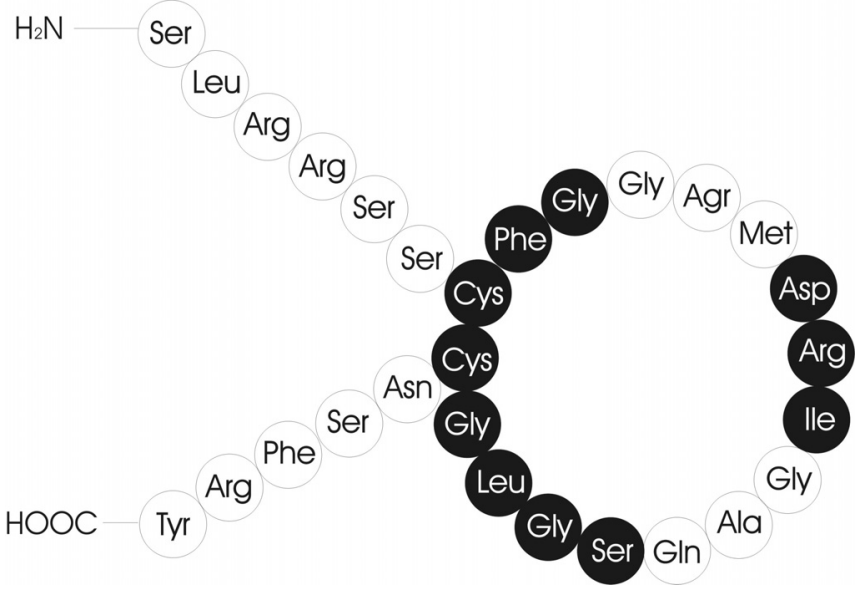

Fig. 1. ANP (1-28), atrial natriuretic peptide, the biologically active hormone. 
physiological role in volume and pressure homeostasis in humans.

In 1956, two separate experiments established the heart as an endocrine organ that synthesises ANP (Henry and Pearce, 1956; Kisch, 1956). Increased cardiac expression and synthesis of ANP or ANP receptors was later found, which suggested a possible local paracrine function in a number of tissues including the eye (Gutkowska and Nemer, 1989; Sales et al., 1991). Primary open-angle glaucoma (POAG) is a public health problem, which is the second leading cause of blindness worldwide (Coleman, 1999). The percentage of affected individuals increases with age (e.g., $1.9 \%$ of Americans $\geq 40$-year-old affected, $7 \% \geq 80$ years) and differs between populations (e.g., 3.6\% Japanese $\geq 40$ years affected) (Libby et al., 2005). The aetiology of POAG is unknown. Several risk factors have been found to be associated with the development of glaucoma. In the 1990s, the first major gene loci for POAG, GLC1A and GLC1B, were described (Gaspar et al., 1991; Dielemans et al., 1994). The GLC1A gene encodes myocilin, the trabecular meshwork-induced glucocorticoid response protein. GLC1A is located on chromosome 1. Mutations in this gene cause raised eye pressure and damage to the optic nerve, but the underlying mechanisms are unknown (Dielemans et al., 1994). Although raised intraocular pressure levels are usually associated with POAG, prediction of the progression from hypertension to glaucoma is difficult (Chauhan and Drance, 1992; Sheffield et al., 1993; Ruben et al., 1994; 1995). Therefore, the identification of genetic markers may prove to be an important advance in the early diagnosis of glaucoma.

POAG is a heterogeneous disease, and elucidation of the underlying genetic mechanisms contributing to phenotypic expression is required for earlier diagnosis of individuals at risk and specific medical treatment. A positive family history of glaucoma is a risk factor. Autosomal dominant pedigrees have linked familial glaucoma to a region on chromosome 1 (1q21-1q 31) (Sheffield et al., 1993; Wiggs et al., 1994), which contains the candidate gene, ANP-receptor A. Several studies have suggested that the ANP system plays a physiological role in the regulation of intraocular fluid homeostasis and intraocular pressure levels in the eye (Mittag et al., 1987; Nathanson, 1987; Diestelhorst and Kriegestein, 1989; Wolfensberger et al., 1994, Tunny et al., 1996). Immunohistochemical studies have localised ANP and BNP to the anterior segment of the eye (ciliary processes, anterior ciliary muscle) (Yamamoto et al., 1991; Palm et al., 1994). The functional significance of the type B (ANP (B)) and type $\mathrm{C}$ (ANP (C)) natriuretic peptide receptors has been investigated in vivo in the rabbit eye by evaluating the effect of intracameral administration of C-type natriuretic peptide (CNP) and C-ANP-(4 -23) on intraocular pressure, and the action of CNP on guanylate cyclase activity in rabbit ciliary-process membranes (Fernandez-Durango et al., 1999). ANP and BNP were also examined for comparison. This study demonstrated that the natriuretic peptides decrease intraocular pressure and stimulate guanylate cyclase activ- ity, CNP being most potent. The expression of natriuretic peptides along with natriuretic peptides receptor transcripts in neural retinal, glial, and vascular elements of the normal adult retina suggests a role for these peptides in maintaining both the neural and vascular integrity of the mature retina (Rollin et al., 2004).

The human ANP gene is localised on chromosome 1 (1p36) (Yang-Feng et al., 1985). The gene is composed of three exons (Exon 1, Exon 2, and Exon 3) and two introns (Intron $\mathrm{A}$ and Intron B). Exon 1 (122 bp) contains the 5 -noncoding region, codon (AUG), 25 amino acid signal peptide sequence and pro-ANP 16 amino acid residues. Exon 2 (327 bp) contains the pro-ANP coding region, which is 125-amino acids long, and Exon 3 encodes the last pro-ANP aminoacid (Tyr). Exon 3 (302 bp) consists also of codon (UGA), the 3 -noncoding region and signal (AAUAAA). The six-nucleotide sequence of the pro-mRNA is recognised by a specific endonuclease. After cleavage of endonucleases, poly (A) polymerase synthesises an additional $\sim 250$ adenine (A) residues. The ANP gene is 2710 nucleotide (nt)-long including Intron A (9122 bp) and Intron B (1110 bp) (Fig. 2). Pro-ANP is stored in membrane-bound granules in atrial cardiocytes. Upon stimulation, these granules move to the cell surface, releasing the stored pro-ANP (1-126). The precise location and identity of this mechanism is still open to debate. This prohormone is cleaved into the mature 28 amino acid ANP, also known as ANP (1-28) or $\alpha$-ANP, and the amino terminal fragment ANP (1-98). The 98 aminoacid N-terminus is further processed proteolytically within the circulation to form pro-ANP (1-30), pro-ANP (31-67) and pro-ANP (79-98) (Fig. 3).

The main goals of the present study were to identify alterations in the ANP gene (genetic variations and promoter

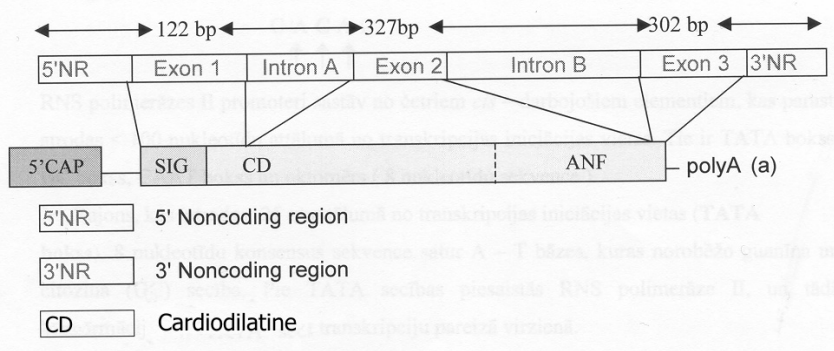

Fig. 2. Biosynthesis of ANP (atrial natriuretic peptide).

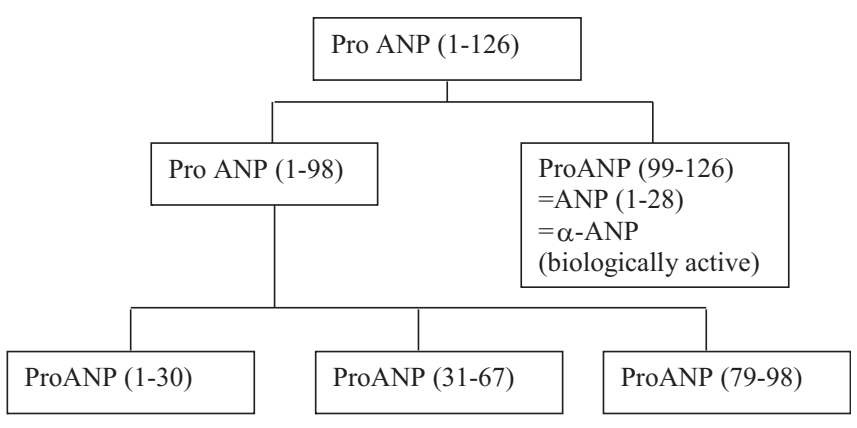

Fig. 3. Human ANP gene structure. 
structure) and to evaluate the pro-ANP level in the blood, in the search for a role of ANP in pathophysiological changes in patients with POAG. Additional aim of our research was to examine the relation between the level of hormone and increased intraocular pressure. We examined the ANP gene using a long-PCR based technique including PCR-RFLP analysis with various restriction endonucleases and PCRSSCP to examine the 5 proximal promoter region of the gene (-595 to transcription start site), which is known to contain regulatory elements affecting gene transcription.

\section{MATERIALS AND METHODS}

We examined 27 patients with primary open-angle glaucoma (essential hypertension in 14 patients and normal blood pressure in 13 patients) and three patients without glaucoma and without blood hypertension as a control. Informed consent of all examined patients was obtained.

Intraocular pressure was measured in all patients on at least three separate occasions by calibrated Goldmann Applanation tonometry. The optic nerve head was examined by direct ophthalmoscopy and Volk 90 binocular slit lamp examination. Computerised visual field assessment was performed by Humphrey perimetry utilising the $30-2$ programme.

Genomic DNA was extracted from peripheral blood leucocytes using the standard phenol-chloroform method as described in Sambrook et al. (1989).

PCR-RFLP analysis of ANP gene. 1344 bp fragment of ANP gene was amplified by a long-PCR based method employing $50 \mathrm{ng}$ of genomic DNA. For 1344 bp fragment amplification a $10 \mu \mathrm{M}$ forward primer 5 GGAAGTCAGCCCAGCCCAGAGAGAT -3` and $10 \mu \mathrm{M}$ reverse primer 5-GCAGTCTGTCCCTAGGCCCA-3 ${ }^{`}$ were used. The ANP gene sequence was taken from Gene Bank (code: K02043). PCR run times were: $2 \mathrm{~min}$ at $93{ }^{\circ} \mathrm{C}, 1 \mathrm{~min}$ at $93{ }^{\circ} \mathrm{C}, 1 \mathrm{~min}$ at $58{ }^{\circ} \mathrm{C}, 1 \mathrm{~min}$ at $72{ }^{\circ} \mathrm{C}, 30$ cycles, and 10 minutes at $72 \mathrm{C}$. Amplification products were electrophoresed on $1 \%$ agarose gel and viewed under UV illumination. A negative control lane containing all reagents except DNA was run under identical PCR conditions for all gels.

Amplified products were digested at $37^{\circ} \mathrm{C}$ overnight using restriction enzymes SmaI and HpaII (Fermentas, Lithuania). Allelic frequencies at the RFLP sites in the ANP gene produced by $S m a \mathrm{I}$ and HpaII were analysed on $6 \%$ polyacrylamide gel. Besides PCR-RFLP analysis with restriction enzymes SmaI and HpaII, allelic frequencies at RFLP site in the ANP gene produced by ScaI were examined (Table 1). For 478 bp fragment amplification the following primers were used: $10 \mu \mathrm{M}$ forward primer 5'TGAGGCAGGAGAATGGCGTGAA-3 3 and $10 \mu \mathrm{M}$ reverse primer 5'-GCAGTCTGTCCCTAGGCCCA-3`.

PCR-SSCP analysis of the proximal promoter region of the ANP gene. For PCR-SSCP analysis the $211 \mathrm{bp}$ fragment was amplified using forward primer
Table 1

INVESTIGATIONS OF ATRIAL NATRIURETIC PEPTIDE (ANP) GENE POLYMORPHISMS

\begin{tabular}{llll}
\hline $\begin{array}{c}\text { Restriction } \\
\text { endonuclease }\end{array}$ & \multicolumn{1}{c}{ Location of restriction site } & Author, publishing year \\
\hline KpnI & $\begin{array}{l}\text { Polymorphism of two alleles } \\
(1,1 ; 1,8)\end{array}$ & Nemer et al., 1984 \\
TaqI & $\begin{array}{l}\text { Polymorphism of two alleles } \\
(1,2 ; 2,8)\end{array}$ & Nemer et al., 1986 \\
XhoI & $\begin{array}{l}\text { Polymorphism of two alleles } \\
(1,6 ; 2,2)\end{array}$ & Nemer et al., 1986 \\
BglI & $\begin{array}{l}\text { Polymorphism of two alleles } \\
(1,3 ; 1,5)\end{array}$ & Frossard et al., 1987 \\
BsmI & $\begin{array}{l}\text { Polymorphism of two alleles } \\
(1,5 ; 1,7)\end{array}$ & Frossard et al., 1987 \\
ScaI, NsiI & $\begin{array}{l}\text { Polymorphism of two alleles } \\
(2235 \text { pos. })\end{array}$ & Masharami et al., 1988 \\
SmaI, HpaII & $\begin{array}{l}\text { Polymorphism of two alleles } \\
(1834 \text { pos. })\end{array}$ & Ramasawmy et al., 1992 \\
XhoI, BglI & $\begin{array}{l}\text { Polymorphism of two alleles } \\
(1,6 ; 1,8)\end{array}$ & Berge et al., 1994
\end{tabular}

5 '-CAGGTGTGAGGCCAGCTT-3` and reverse primer 5-GGTTATCTCACCGCCGTG-3`. PCR conditions were: initial denaturation $5 \mathrm{~min}$ at $94 \mathrm{C}$, denaturation $1 \mathrm{~min}$ at $94 \mathrm{C}$, hybridisation $1 \mathrm{~min}$ at $62{ }^{\circ} \mathrm{C}$, elongation $90 \mathrm{~s}$ at $72{ }^{\circ} \mathrm{C}, 30$ cycles, final elongation $10 \mathrm{~min}$ at $72{ }^{\circ} \mathrm{C}$.

PCR product sequencing. 211 bp PCR fragments before sequencing reaction were purified from agarose gel with a DNA Extraction kit (Fermentas, Lithuania). Purified 211 bp PCR fragments were sequenced using the Cycle Reader ${ }^{\text {TM }}$ DNA Sequencing kit (Fermentas, Lithuania) according to the manufacter's protocol on a ABI PRISM 310 genetic analyser (Applied Biosystems, USA).

Plasma pro-ANP concentration in patients with primary open-angle glaucoma. The pro-ANP level in plasma of POAG patients was determined by enzyme immunoassay (ELISA). This method is simple, safe and sensitive $(\sim 5 \times$ $\left.10^{-16} \mathrm{~mol}-1 \times 10^{-17} \mathrm{~mol}\right)$. We used Competitive Enzyme Immunoassay for the quantitative determination of proANP in biological fluids (Biomedica). According to the manufacter's protocol, characteristic sizes of pro-ANP level were found to be lower than $1.32 \mathrm{nmol} / \mathrm{ml}$ with fluctuation 0-5 nmol/ml. Blood samples were collected from 30 patients: 14 patients had POAG and essential hypertension, 13 patients had POAG and normal blood pressure, and three patients were without glaucoma and with normal blood pressure.

\section{RESULTS}

Diagnosis of primary glaucoma was confirmed to all 27 patients, since two of three variables occurred simultaneously: intraocular pressure was consistently greater than or equal to $21 \mathrm{~mm} \mathrm{Hg}$, the optic nerve head cup: disc ratio was greather than or equal to 0.6 , or glaucomatous visual field loss was characteristic. 
Of 27 glaucoma patients studied, to 24 ( $90 \%)$ was observed elevated level of pro-ANP in plasma- 2.3-42 $\mathrm{nmol} / \mathrm{ml}$ (normal level is below $1.32 \mathrm{nmol} / \mathrm{ml}$ ). Hovewer, 14 patients had POAG and essential hypertension. At the same time, there was elevated pro-ANP level in PAOG patients with normal haemodynamic indices. All patients without PAOG and hypertension were with a normal level of pro-ANP.

Successful amplification of 1344 bp structural gene and 478 bp promoter fragments of ANP gene have been performed and suitable for restriction cleavage pure amplicones obtained (Figs. 4 and 5).

The produced fragments after digestion of the $1344 \mathrm{bp}$ long fragments with HpaII are shown in Figure 6. As it can be

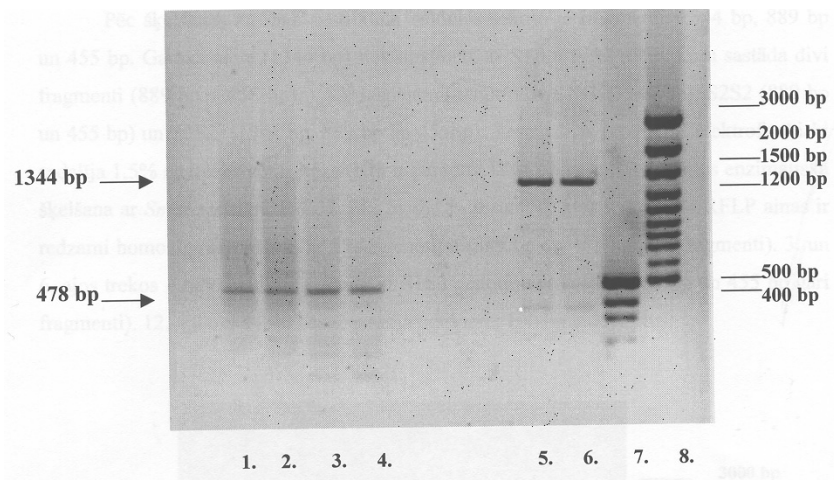

Fig. 4. Electrophoreses analysis of 1344 bp and 478 bp amplified products in 1.2\% agarose gel. Tracks 1-4 - 478 bp PCR products; tracks 5-6 - 1344 bp PCR products; track 7 - pU19 DNA/MspI size marker; track 8-100 bp DNA ladder plus size marker.

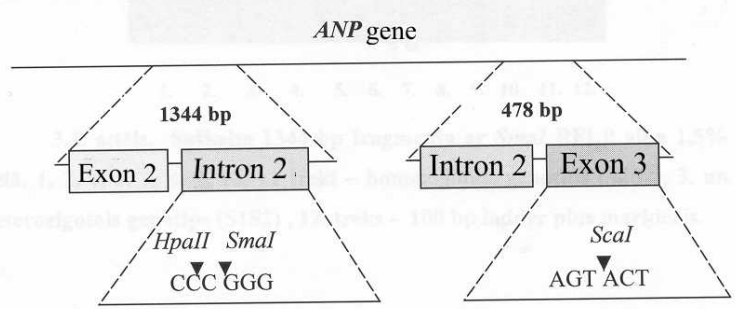

Fig. 5. Polymorphic sites of the ANP gene.

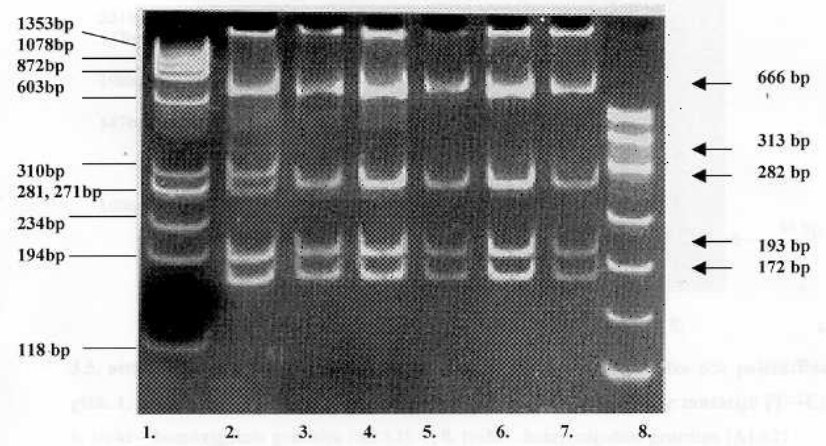

Fig. 6. PCR-RFLP analysis of the 1344 bp products digested with HpaII in $6 \%$ polyacrylamide gel. Track 1 - ÖX174 DNA/HaeIII size marker; track 2 - heterozygote genotype; tracks 3-7 - homozygote genotypes; track 8 pUC19 DNA/MspI size marker. seen, no significant difference was observed in the frequency of the polymorphisms of ANP gene alleles and genotypes between the hypertensive patients and the control group. The PCR-RFLP analysis using Sca I restriction endonuclease and nucleotide sequencing of the ANP gene revealed a $\mathrm{T} 2238 \rightarrow \mathrm{C}$ transition within a stop codon in three hypertensive patients. No significant alterations in the 5 proximal promoter region of the ANP gene were observed also among hyperternsive patients.

\section{DISCUSSION}

The obtained results about pro-ANP level in blood and intraocular pressure suggest associations between POAG and natriuretic peptides (NP). More clearly such association may be evaluated by analysis of BNP and ANP in human aqueous humour, however this is an invasive method and therefore is not widely used (Salzmann et al., 1998). Welldocumented increase of NP levels in hypertension and cardiac insufficiency from the other side limits using of peptide blood tests, but analysis of natriutretic peptides in normotensive patients should be recommended for introduction in ophthalmologic clinic. The immunoenzymatic methods (ELISA) are well suited for the determination of NP in patients with glaucoma, heart diseases and increased blood pressure, and it can be also used to diagnose the general condition of organism (Rubattu et al., 2006; 2007; Jeoung et al., 2007).

Moreover, registered lowering of intraocular pressure upon intravitreally injected natriuretic peptide in rabbits strongly suggest that NP plays an important role in the control of intraocular pressure (Takashima et al., 1996). Observed in our studies normal level of NP in blood of POAG patients may be considered as indication for using of NP in therapy hence. Mechanisms of NP level regulation in organism are still enigma, where gene structure or expression problems may be suspected. Our studies allow express such speculations, since $\mathrm{T} 2238 \rightarrow \mathrm{C}$ mutation within a stop codon of the ANP precursor gene was found in hypertensive patients. Anlysis of the promoter region, however, did not show any mutations or polymorphisms and our findings may suggest that the expression regulated elements in this promoter $-595 b p--384 b p$ region are not connected with the development of hypertension and increased intraocular pressure. Therefore, our studies indicate the prospectivity of natriuretic peptide studies in glaucoma patients in order to get additional information about glaucoma pathogenesis and possible application of these peptides in therapy.

In conclusion:

- Using the PCR-RFLP method with ScaI restriction endonucleasis and sequencing analysis of the appropriate products, for three hypertensive samples, a mutation forming an arginine residue was found and localised in STOP codone $(\mathrm{T} 2238 \rightarrow \mathrm{C})$. 
- PCR-SSCP method for polymorphism detection was employed using the 5'proximal promoter region of the gene. Mutations were not found among the 30 clinical samples. It can be assumed that this region is not connected with the development of glaucoma

- Studies of natriuretic peptides in glaucoma patients should be recommended in ophthalmologic clinics.

\section{AKNOWLEDGMENTS}

The study was supported by a grant from the Latvian Council of Science National programme No. 05.0023.

\section{REFERENCES}

Berge, K., Berg, K. (1994). No effect on blood pressure level or variability of polymorphisms in DNA at the locus for atrial natriuretic factor (ANF). Clin. Genet., 46, 433-435.

Chauhan, B.C., Drance, S.M. (1992). The relationship between intraocular pressure and visual field progression in glaucoma. Graefes Arch. Clin. Exp. Ophthalmol., 230, 521-526.

Coleman, A.L. (1999). Glaucoma. Lancet, 354, 1803-1810.

de Bold, A.J., Borenstein, H.B., Veress, A.T., Sonnenberg, H. (1981). A rapid and potent natriuretic response to intravenous injection of atrial myocardial extracts in rats. Life Sci., 28, 89-94.

Dielemans, I., Vingerling, J.R., Wolfs, R.C., Hofman, A., Grobbee, D.E., de Jong, P.T. (1994) The prevalence of primary open-angle glaucoma in a population-based study in the Netherlands. The Rotterdam Study. Ophthalmology, 101, 1851-1855.

Diestelhorst, M., Krieglstein, G.K. (1989). The intraocular pressure response of human atrial natriuretic factor in glaucoma. Int. Ophthalmol., 13, 99-101.

Fernandez-Durango, R., Moya, F.J., Ripodas, A., de Juan, J.A., Fernandez-Cruz, A., Bernal, R. (1999). Type B and type C natriuretic peptide receptors modulate intraocular pressure in the rabbit eye. Eur. J. Pharmacol., 364, 107-113.

Frossard, P.M, Coleman, R.T, Morrison, N.A. (1987). Human natriuretic peptides (ANP) gene locus: BsmI RFLP. Nucleic Acids Res., 15, 7656.

Gaspar, L., Fernandez-Durango, R., Seidah, N.G., Chrétien, M., Gutkowska, J. (1991). ANF mRNA is detected by the polymerase chain reaction technique in the chorioidea and bodies but not in the retina of the rat eye. Endocrinology, 129, 559-561.

Gutkowska, J., Nemer, M. (1989). Structure, expression, and function of atrial natriuretic factor in extraatrial tissues. Endocrin Rev., 10, 519-536.

Henry, J.P., Pearce, J.W. (1956). The possible role of cardiac stretch receptors in the induction of changes in urine flow. J. Physiol., 131, 572-594.

Jeoung, J.W., Kim, D.M., Ko, H.S., Park, S.S., Kim, J.Y., Kim, S.Y., Yoo, T.W. (2007). Investigation of the association between normal-tension glaucoma and single nucleotide polymorphisms in natriuretic peptide gene. Korean J. Ophthalmol., 21, 33-38.

Kisch, B. (1956). Electron microscopy of the atrium of the heart. Exp. Med. Surg., 14, 99-112.

Lang, M., Dealean, A., Garcia, R., Cantin, M. (1990). Synthesis and biological activity profiles of atrial natriuretic factor (ANF) analogs. Int. J. Peptide Protein Res., 36, 156-160.

Libby, R.T., Gould, D.B., Anderson, M.G., John, S.W. (2005). Complex genetic of glaucoma susceptibility. Annu. Rev. Genomics Hum. Genet., 6, $15-44$.

Masharami, U., Nakashima, P.F., Lim, D.W. (1988). NsiI and ScaI restriction fragment length polymorphisms at the atrial natriuretic peptides (ANP) gene locus. Hum. Genet., 80, 307-308.
Mittag, T.W., Tormay, A., Ortega, M., Severin, C. (1987). Atrial natriuretic peptide (ANP), guanylate cyclase, and intraocular pressure in the rabbit eye. Curr. Eye Res., 6, 1189-1196.

Nathanson, J.A. (1987). Atriopeptin-activated guanylate cyclase in the anterior segment. Identification, localization, and effects of atriopeptins on IOP. Invest. Ophtalmol. Vis. Sci., 28, 1257-1364.

Nemer, M., Sirolis, D., Drouin, J. (1984). KpnI polymorphism at the human pronatriodilatin (hPND) gene locus. Nucleic Acids Res., 19, 7245-7246.

Nemer, M., Sirolis, D., Drouin, J. (1986a). TaqI polymorphism at the 3' end of the human pronatriodilatin (hPND) gene locus. Nucleic Acids Res., 14, 8697-8698.

Nemer, M., Sirolis, D., Drouin, J. (1986b). XhoI polymorphism at the human pronatriodilatin (hPND) gene locus. Nucleic Acids Res., 14, 8696-8697.

Palm, D.E., Keil, L.C., Sewers, W.B. (1994). Angiotensin, vasopressin and natriuretic peptide in the rat eye. Proc. Soc. Exp. Biol. Med., 206, 392-395.

Ramasawmy, R., Kotea, N., Lu, C., Sayada, C., Baligadoo, S., Krishnamoorthy, R. (1992). A new polymorphic restriction site at the human atrial natriuretic peptide (hANP) gene locus. Hum. Genet., 91, 509-510.

Rollin, R., Mediero, A., Roldan-Pallares, M., Fernandez-Cruz, A., Fernandez-Durango, R. (2004). Natriuretic peptide system in the human retina. Mol. Vis., 10, 15-22.

Rosenzweig, A., Seidman, C. (1991). Atrial natriuretic factor and related peptide hormones. Annu Rev. Biochem., 60, 229-235.

Rubattu, S., Bigatti, G., Evangelista, A., Lanzani, C., Stanzione, R., Zagato, L., Manunta, P., Marchitti, S., Venturelli, V., Bianchi, G., Volpe, M., Stella, P. (2006). Association of atrial natriuretic peptide and type A natriuretic peptide receptor gene polymorphisms with left ventricular mass in human essential hypertension. J. Amer. Coll. Cardiol., 48, 499-505.

Rubattu, S., Evangelista, A., Barbato, D., Barba, G., Stanzione, R., Iacone, R., Volpe, M., Strazzullo, P. (2007). Atrial natriuretic peptide (ANP) gene promoter variant and increased susceptibility to early development of hypertension in humans. J. Hum. Hypertens., 2, 822-824.

Ruben, S.T., Hitchings, R.A., Fitzke, F., Arden, G.B. (1994). Electrophysiology and psychophysics in ocular hypertension and glaucoma: Evidence for different pathomechanisms in early glaucoma. Eye, 8, 516-526.

Ruben, S.T., Arden, G.B., O’Sullivan, F., Hitchings, R.A. (1995). Pattern electroretinogram and peripheral colour contrast thresholds in ocular hypertension and glaucoma: Comparison and correlation of results. Brit. J. Ophthamol., 79, 326-331.

Sales, N., Dutriez, I., Maziere, B., Ottaviani, M., Roques, B.P. (1991). Neutral endopeptidase 24.11 in rat peripheral tissues: comparative localization by ex vivo and in vitro autoradiography. Reg. Peptides, 33, 209-222.

Salzmann, J., Flitcroft, D., Bunce, C., Gordon, D., Wormald, R., Migdal, C. (1998). Brain natriuretic peptide: Identification of a second natriuretic peptide in human aqueous humour. Brit. J. Ophthalmol., 82, 830-834.

Sambrook, J., Fritsch, E.F., Maniatis, T. (1989). Molecular Cloning: A Laboratory Manual. 2nd edn. Cold Spring Harbor, NY: Cold Spring Harbor Laboratory Press. 1659 pp.

Sheffield, V.C., Stone, E.M., Alward, W.L., Drack, A.V., Johnson, A.T., Streb, L.M., Nichols, B.E. (1993). Genetic linkage of familial open angle glaucoma to chromosome 1q21-q31. Nat. Genet., 4, 47-50.

Takashima, Y., Tniguchi, T., Yoshida, M., Haque, M.S.R., Yoshimura, N., Honda, Y. (1996). Invest. Ophthalm. Visual Sci., 37, 267-2677.

Tunny, T.J., Richardson, K.A., Clark, C.V., Gordon, R.D. (1996). The atrial natriuretic peptide gene in patients with familial primary open-angle glaucoma. Biochem. Biophys. Res. Commun., 223, 221-225.

Wei Yan, Faye Wu, Morser, J., Qingyu Wu. (2000). Corin, a transmembrane cardiac serine protease, acts as a pro-atrial peptide-converting enzyme. PNAS, 97, 8525-8529.

Wiggs, J.L., Haines, J.L., Paglinauan, C., Fine, A., Sporn, C., Lou, D. (1994). Genetic linkage of autosomal dominant juvenile glaucoma to 1q21-q31 in three affected pedigrees. Genomics, 21, 299-303. 
Wolfensberger, T.J., Singer, D.R.J., Freegard, T., Mankandu, N.D., Buckley, M.G., MacGregor, G.A. (1994). Evidence for a new role of natriuretic peptides: Control of intraocular pressure. Brit. J. Ophthalmol., 78(6), 444-448.

Received 21 January 2008
Yamamoto, R., McGlinn, A., Stone, R.A. (1991). Brain natriuretic peptide-immunoreactive nerves in the porcine eye. Neurosci. Let., 122, 151-153.

Yang-Feng, T.L., Floyd-Smith, G., Nemer, M. (1985). The pronatriodilatin gene is located on the distal short arm of human chromosome 1 and on mouse chromosome 4. Amer. J. Hum. Genet., 37, 1117-1128.

\section{ĀTRIJA NATRIURĒTISKAIS PEPTĪDA GĒNS, PLAZMAS pro-ANP KONCENTRĀCIJA PACIENTIEM AR PRIMĀRU ATVĒRTA KAKTA GLAUKOMU}

Ātrija natriurētiskais peptīds (ANP) piedalās šķidrumu un spiediena homeostāzes regulācijā, veicot natriurēzi, diurēzi un inhibējot renīna-angiotenzīna-aldosterona sistēmu. ANP ekspresējas un sintezējas ne tikai sirdī, bet arī citos audos - hormons veic parakrīno funkciju vairākos orgānos, tajā skaitā acīs. Tādēḷ genētisko marḳieru identificēšana var noderēt par būtisku glaukomas un hipertenzijas diagnosticēšanas veidu. Plazmas pro-ANP koncentrācija tika noteikta 30 klīniskiem paraugiem. Prehormona paaugstināts līmenis tika novērots pacientiem ar glaukomu un hipertensiju. Tika veikti ANP gēna polimorfisma pētījumi, lai noteiktu genotipu un alęḷ frekvences 20 hipertensīviem un normotensīviem klīniskiem paraugiem, izmantojot restrikciju fragmentu garumu polimorfisma metodi (RFLP), škeḷot ar ScaI, HpaII un SmaI restriktāzēm. Starp hipertensīviem un normotensīviem klīniskiem paraugiem genotipu un alēḷu frekvenču atškiirības netika novērotas. Pēc šḳelšanas ar ScaI restriktāzi, izmantojot RFLP analīzi un nukleotīdu sekvenēšanu, trim hipertensīviem pacientiem tika lokalizēta mutācija ANP gēna stop-kodonā. PCR produktu sekvenēšana norādīja, ka ScaI restrikcijas saita zudums ir saistīts ar nukleotīdu nomaiṇu $(\mathrm{T} 2238 \rightarrow \mathrm{C})$, kuras rezultātā veidojas arginīna atlikums. Šajā pētījumā tika arī analizēts ANP gēna 5'proksimālais promotera rajons 20 normotensīviem un hipertensīviem pacientiem. Šim nolūkam tika izmantota PCR - SSCP (single strand conformation polymorphism) metode, lai konstatētu iespējamās punktveida mutācijas ANP gēna 5'proksimālā promotera rajonā (-595 bp - -384 bp), kas satur gēna transkripcijas regulējošus elementus. Divdesmit klīniskajiem paraugiem šajā promotera rajonā netika konstatētas mutācijas. Mūsu ANP hormona gēna struktūras pētījumi parādīja tā potenciālo nozīmi dažādu patoloğisko procesu izcelsmē, bet par tā ietekmi uz acīm nepieciešami turpmāki pētījumi. 